\title{
Main trends in Hungarian agriculture ${ }^{1}$ )
}

\author{
GÁBOR SzABó, \\ Institute of Economics, Hungarian Academy of Sciences, Budapest
}

Received September 14, 1973

\begin{abstract}
In Hungary the establishment of cooperative farms has radically changed the organizational conditions of production. Nowadays almost three quarters of the agricultural production comes from the co-operative sector. However, the production of small household plots is significant with respect to certain farm products. Thus, 65 per cent of the eggs, $43-46$ per cent of the wine, 33-35 per cent of the milk, 30-33 per cent of the slaughtered cattle, 29 per cent of the fruits and 13-15 per cent of the slaughtered pigs come from small privately farmed plots. The efficiency of Hungarian agriculture has developed rapidly since the early $1960 \mathrm{~s}$. This is reflected in the increase of average per hectare yields. In the late $1960 \mathrm{~s}$ two substantial price rises occurred in agriculture. Experience since then shows that with the introduction of the reform and with the rise in the price level the role and scope of prices has become greater and wider. Nowadays it is believed that it is possible to manage farms successfully without compulsory plan directions using more economic regulators instead.
\end{abstract}

The last fifteen years brought radical changes in the organizational set-up, output and capacity of Hungarian agriculture. There is no doubt that the land reform effected after the Second World War was of historic significance in the life of the Hungarian peasantry by putting the land into the hands of those who cultivate it. This, however, resulted in a considerable increase of small farms over large ones, which made it impossible for Hungarian agricultural production to advance according to modern requirements since small-scale farms are nowhere in the world able to keep pace with large ones.

\section{The road to large-scale farms}

Efforts were begun already in 1949 to establish large-scale farms to meet the requirements of faster development. The aim was to get the vast majority of the working peasants to join cooperative farms where large-scale methods

1) Lecture given at the meeting of Finnish agricultural economists in Helsinki on May 28, 1973. Abstract and the Finnish review have been written, at the editor's request, by Mr. Juhani Rouhiainen, Lic. of Agriculture and Forestry. 
could be utilized and thus to start raising agricultural production and the living standard of the peasantry. The decisive change came in 1961 with the completion of the process of establishing large-scale socialist farms, after the Hungarian peasantry had begun to join the cooperatives really almost e $n$ $\mathrm{m}$ a s e in the spring of 1959.

This transformation of agriculture radically changed the organizational conditions of production, not only because most of the labour power, the productive area of the country and the livestock became concentrated in the large farms. Nowadays almost three quarters of the agricultural production come from the co-operative sector and 90 per cent of the same is jointly yielded by the co-operative and state sector. The transformation was important also because the vast majority of the still existing small farms are now the household plots of co-operative members, and these household plots are an integral part of the collective large-scale farms in every way, while the work in the households plots is done by the same people who experience modern methods of farming in the collective farms.

Moreover the co-operative makes available for its members fodder for household plots, and often even the fertilizers and improved high-yielding seeds as well as expert advice. This means in effect that up-to-date agricultural methods are much more widely used on the household plots than was the case on the small farms.

\section{Changes in the structure of production}

Since 1961 essential positive changes have taken place in the structure and technology of agricultural production. In the Hungary of the $1950 \mathrm{~s}-$ as everywhere where industrialization and municipal development was strong - the amount of land available for agriculture was reduced. Large areas of land were taken up by new industrial establishments, new roads and railways; the large-scale expansion of cities and towns and the creation of new towns also made their inroads on agriculture. The approximately 293,000 hectares of land area used for the above purposes decreased the agricultural area existing at the end of the 1940 s by approximately 4 per cent.

Beginning with the early 1960 s an attempt was made to make up for this decrease through more intensive cultivation of the remaining agricultural area; from 1961 to 1965 inclusive, largescale vineyards and fruit orchards were planted, increasing their relative proportions to the detriment of meadow, pasture and arable land. In fact the land turned over to vineyard and orchards was mainly sandy soil illsuited for field crops. At the same time the cultivation of crop area was also intensified and the area sown with high-value crops, especially greens and vegetables, increased.

\section{The increase of production}

Between 1945 and 1956 we could not solve the b r e a d- g r o w q u e s t i o $\mathrm{n}$ in this country. After 1960 , we could - throught the socialist reorganization of 
agriculture - in a matter of less than a decade! Between 1961 and 1965 the average yield per hectare of wheat was 18,9 quintals, the average of the period of 1966-1970 was 24,3 quintals, but the yield of the wheat grew up to 30,7 quintals per hectare in 1971.

There is no doubt that this relatively high level of wheatgrowing could not have been attained without a high state purchase price. But, there have been other very important factors - the widespread use of modern kinds of foreign intensive wheat, first of all Besostaya 1, the increase in artificial fertilizer sypply, the almost complete mechanization of tilling and harvesting and further, agrotechnical discipline. Besides these, of great significance have been some up-to-date methods of state purchase and in improvement in storing conditions.

We have attained an increase in c o r $\mathrm{n} \mathrm{y} \mathrm{i} \mathrm{e} \mathrm{l} \mathrm{d} \mathrm{s} \mathrm{too,} \mathrm{and} \mathrm{resultant} \mathrm{upon}$ this, better profitability when we bred up-to-date hybrid plants and began to use hybrid varieties. The use of up-to-date varieties was followed by mechanized sowing of the grain, the increase in the number of stems, the use of artifical fertilizers in larger doses, the use of superselective weed killers, and the gradual extension of the watered area. The mechanization of harvesting, transportation, drying and storing is being carried through these years. Compared with the average yield per hectare of 26,1 quintals in the years between 1961 and 1965, the average on the national level of corn yield being 32,3 quintals between 1966 and 1970 and 35,4 in 1971 .

The increase in vegetable production and the fact that they farm continuously a higher share in agriculture is also closely connected with the development of large-scale methods. This is true even though the quantity of greens and vegetables grown on household plots and even in the gardens of the population is also important not only for the personal consumption of the products but also for urban supplies.

As for vegetables, in Europe only Italy and Bulgaria have similar percapita production. The large quantities of vegetables grown in Hungary, however, far exceed the requirements of the population. An important part of the total yield is processed by canning factories. In addition, a relatively large quantity -7 per cent of the total produce - is exported raw.

The development of $\mathrm{fruit}$ production, even more dynamic than that of greens and vegetables, was the result of the planting, from 1961 to $\mathbf{1 9 6 5}$, of over 58,000 hectares of new fruit orchards, largely on state and cooperative farms, most of which bore fruit by 1969 .

The composition of these new orchards was also favourable. The new plantations were mostly made up of apples, peaches and berries, chiefly strawberries. Most of the apple-trees bear the Jonathan and Starking varieties which last until the late autumn and winter months, are rich in vitamins and pleasing to the palate.

Besides satisfying the important needs of the population, the dynamic growth of the fruit production contributes considerably to the foreign trade of the country, helping to improve the balance of payments. A third important factor in largescale fruit plantations is that these new orchards were planted mainly in areas where sufficient labour could be found, and secondly where 
fruit would give relatively much higher yields than any other kind of field crops.

The economic factors which necessitate maintaining $\mathrm{viticult}$ u re and $\mathrm{v}$ in e production at a high level in Hungary are essentially the same as those which justify fruit production. That is why 47,000 hectares of new viticultures were planted in Hungary between 1961 and the end of 1965, chiefly within the framework of the large-scale co-operatives and state farms.

But even with these new plantations the small-scale methods of production still prevail in viticulture.

Per capita vine production exceeded 52 litres a year, placing Hungary fifth or sixth in per-capita grape and wine production. There are significant exports, too, especially of wine.

A similar development has been attained in large-scale po u $1 \mathrm{t} r \mathrm{y} \mathrm{r}$ e a ri $\mathrm{ng}$. This is due in pariicular to our having succeeded in finding abroad a suitable up-to-date complex rearing technology, in adapting it to our own needs, and in extending it for wide use in this country. There has been a successful combination of the most fertile hybrid species, of feedstuffs, of buildings, of technological facilities, and of know-how forming a complex industrial system.

After having carried through the programs of intensively planting wheat, hybrid corn, grapes and fruits, and the extension and consolidation of large-scale poultry rearing, we began the energetic extension of industrial methods in pig rearing and fattening, first of all in the corn-production regions. So far, about 240 large cooperative farming societies and interco-operative associations have introduced industrial methods in pig rearing and fattening. These produce 2,2 million fattened pigs in 1973.

In c a t t le-rearing we have not yet developed such an industrial technology as was generally adopted in poultry and pig rearing.

\section{The importance and the role of the household plots}

An important principle of our economic policy is that the household plot farm constitutes an organic part of agricultural co-operative farming society management and work done there serves socialist social production and so forms an essential part of planning considerations.

The significance of household plot farms is best reflected in the figures showing their proportion in agricultural production. According to those figures, 33-35 per cent of the milk, 65 per cent of the eggs, 29 per cent of the fruit, $43-46$ per cent of the wine, $30-33$ per cent of the slaughtered cattle, and 13-15 per cent of the slaughtered pigs produced in agriculture come from the household plot farms.

Nor is the significance of the household plots less from the point of view of social policy. They promote the additional employment of otherwise unused so-called "fractionals labour force supplementing co-operative farming societys' working power and the full utilization of farm buildings and other means of production. 
The above-mentioned factors will favourably influence the economic situation and the living standard of the peasantry. Nowadays a family working in a co-operative farming society gets about 40 per cent of its total yearly income from the household plots.

\section{$V$. The effect of the reform of the economic management on the Hungarian agriculture}

The most important step taken by our reform of economic management can be seen in that it has created a more favourable atmosphere for agricultural and food production. The selfreliance of agricultural plants could not earlier develop because then the price returns in the majority of holdings did not, under the conditions of low agricultural producer price levels, cover the costs of reproduction on an increasing scale, and, at a large number of holdings, not even those of simple reproduction.

Under the third five-year plan, according to the objectives set by the 9 th Party Congress, we have taken efficient measures for the gradual development of the monetary selfreliance of the agricultural plants and for making production pay more. So, in the course of settling credits, the remainder of credit liabilities allowed earlier for the purpose of the noriginal accomulation" of the agricultural plants, was cancelled. Further, in 1966 there was a 9 per cent rise in the producer price level, and another, 8.5 per cent rise two years later. With that two-grade prise rises we have taken an important step in agriculture, too, on the road to a gradual development of a price system proportionate to expenditure. Further, the price subsidy system of agriculture has also been based on new principles.

Thus, with the regulating system created with the introduction of the reform - and with the rise in the price level - the role and scope of prices has become greater and wider, agricultural large-scale plants have been in a position to carry on their activities in a more favourable economic climate. As a consequence of all this, the financial-material funds of the productive plants have increased to a great extent, and the conditions of selfreliant ent $\epsilon$ r prise like management have been widely created for agricultural plants, too.

A favourable effect of this is shown in that with the growing rate of production, the extent of employment, the number of expended working-days per head, and the income of bread-winners have increased. As a consequence of all this, the decrease in the number of agricultural workers which had been severe, and their steady migration to the towns, has slowed down.

The experiences gained in recent years, the growth of agricultural production which had become larger than expected, the balanced and secure domestic food sypply, and the growth of exports, which had also become greater than expected - prove that it is possible to manage farms successfully without compulsory plan directions both in the whole national economy and in particular in food economy. The planned development of management can be attained by using economic regulators, and so it can be attained more efficiently.

We have not, of course, developed our national economy or for that matter, our agriculture for their own sake. In 1970 the real wages of the workers and 
employees surpassed the 1950 level by 90 per cent. Real incomes, however, have during the same period of time, due to a fast rise in employment and social benefits, increased two-and-a-half-fold. The real consumption by the peasantry has risen twofold; their incomes had for a period of time lagged behind those of the workers, yet they have in the last few years (excepting the very last) grown somewhat faster than those of the workers and employees. As a consequence, the value of real consumption by the peasantry is very nearly approaching the incomes of the workers and employees.

\title{
LITERATURE
}

FeHER, L. 1971. Current Problems of our Co-operative Policy. Co-operative Research Institute Year-book, 1971: 9-49.

Hungary To-day, 1971.

Statistical Year-book, 1972.

\section{SELOSTUS}

\section{Unkarin maatalouden viimeaikainen kehitys ${ }^{1}$ )}

\author{
GÁBOR SzABó \\ Institute of Economics, Hungarian Academy of Sciences, Budapest
}

Sodan jälkeen on Unkarin maatalous kokenut huomattavan rakennemuutoksen. Pienistä yksityisistä tiloista on vuoteen 1961 mennessä muodostettu suuria osuustoiminnallisia yrityksiä. Nykyään osuustoiminnalliset tilat vastaavat lähes $75 \%$ maatalouden kokonaistuotannosta. Osuustoiminnallisten ja valtion tilojen yhteenlaskettu osuus on $90 \%$. Tästä huolimatta on pienillä yksityisesti hoidetuilla maapalstoilla, jotka ovat osuustoiminnallisten tilojen yhteydessä, tärkeä merkitys eräiden tuotteiden tuotannossa. Niinpä esimerkiksi $65 \%$ kananmunista tuotetaan osuustoiminnallisen sektorin ulkopuolella. Muiden tuotteiden osalta vastaavat luvut ovat seuraavia: viini $43-46 \%$, maito $33-35 \%$, naudanliha $30-33 \%$, hedelmät $29 \%$ ja sianliha $13-15 \%$.

Maatalouden nopea kehitys käy selvästi ilmi hehtaarisatojen kohoamisena. Vuonna 1971 oli vehnän hehtaarisato noussut $62 \%$ vuosien 1961-65 keskimääräisestä tasosta. Vastaava luku maissin kohdalta on $36 \%$. Hedelmien tuotantoon on kiinnitetty entistä enemmän huomiota. Vuosina 1961-65 istutettiin yhteensä 58000 ha uusia hedelmätarhoja. Hedelmien ulkomaankaupalla on nykyään merkitystä valuuttatulojen hankkijana ja maksutaseen tasapainottajana. Hedelmänviljelyn tarkoituksena on ollut myös toteuttaa aluepolitiikkaa perustamalla tarhoja sinne missä työvoimaa on saatavana. Samoihin päämääriin on pyritty viininviljelyksen lisäämisellä. Vuosina 1961 -65 perustettiin yhteensä 47000 ha uusia viinitarhoja.

Vuosina 1966 ja 1968 maatalouden tuottajahinnat nousivat vastaavasti $9 \%$ ja $8.5 \%$. Hintojen nousu yhdessä rakenteellisten muutosten kanssa on antanut suotuisan sysäyksen maatalouden kehittämiselle edelleen. Samalla ovat hinnat tuotannon ohjaamisessa ja resurssien allokoinnissa saaneet entistä tärkeämmän merkityksen. Nykyään uskotaan hintapoliittisin keinoin päästävän tehokkaampaan tuotantoon kuin soveltamalla pelkästään jäykkää suunnitelmallisuutta.

1) Esitelmä, jonka tohtori Szabó piti maanviljelystalouden ryhmän kokouksessa Helsingissä 28.5.1973. Suomenkielisen selostuksen samoin kuin abstract-osan on toimituksen pyynnöstä laatinut maat.-metsät. lis. Juhani Rouhiainen. 